\title{
Management of Ancol Regency Object Facilities Sarolangun
}

\author{
Lise Asnur $^{1}$, Roza Putriana ${ }^{2}$ \\ \{lise.asnur@fpp.unp.ac.id\} \\ Tourism Department, Universitas Negeri Padang, Indonesia ${ }^{12}$
}

\begin{abstract}
This research tittle is management of Ancol Regency Object Facilities Sarolangun. The purpose of this research is to describe the management of the object facilities Ancol Tourism in Sarolangun Regency. This research consists of three facility indicators, main facilities, supporting facilities, and complementary facilities direction, organization, direction and supervisor. This research is a qualitative descriptive research with survey methods. Data collection was carried out by means of observation, interviews, and documentation. The number of informants in this research 5 people, involving the District Office of Culture, Tourism, Youth and Sports Sarolangun, manager of the Sarolangun Regency Ancol Tourism Object. local society Ancol Tourism Object, Sarolangun Regency. The results of this study indicate that management of facilities at Ancol Tourism Object, Sarolangun Regency is not yet structured with good Planning made by the tourism agency is still slowly to advancing Ancol Tourism Object in Saolangun Regency. It can be seen that existing facilities have not made visitors comfortable. Therefore, expected to the management and the Tourism Office to always supervise existing facilities as well as organizing and maintaining existing facilities in order comfortable visitors. And future planning for the Tourism Office can be serious to build additional facilities at the Ancol Tourism Object, Sarolangun Regency.
\end{abstract}

Keywords: Sarolangun Regency; Ancol Facility; Management

\section{Introduction}

Tourism is a sector that is considered to have an important role in the development of a country, tourism can directly contribute more on local income where the tourist attraction is located. The tourism sector can serve as one of the leading sectors in economic improvement, creation employment This is in accordance with Law No. 10 of 2009 states that tourism has an important role to expand and distribute employment opportunities, encourage regional development, and enlarge national income in order to improve welfare and prosperity public.

Ancol is a tourist destination in Sarolangun district, Ancol has many the scenery around it, such as the flow of the Batang Asai river, besides that there is also a new tour called the edge of Cikminah, therefore Ancol is a tourist spot which is good for tourists to relax because it is surrounded by many other tourist spots, and more Ancol tourist attractions are used as venues for events such as 17 August celebration, the celebration of Eid al-Fitr every year, besides there are tourist attractions in In Ancol, there are also prayers for Muslims that are not far away and can be reached on foot from Ancol. 


\section{Methodology}

This type of research is a descriptive qualitative type with a survey method. Data obtained will be analyzed and interpreted in accordance with the objectives and questions research that has been stated. As stated by Sugiyono (2018: 48-49), "Stating that descriptive research is research conducted to determine value independent variable, either one or more (independent) variables without making comparisons, or linking to other variables, which the research does not make comparison of that variable to other samples and looking for the relationship between those variable and other variables ". The data source was five informants consisting of two people The Department of Culture, Tourism, Youth and Sports of Sarolangun Regency, two people Manager of Ancol Tourism Object, Sarolangun Regency and one local community Ancol Tourism Object, Sarolangun Regency.

\section{Result and Discussion}

\subsection{Ancol profile of Sarolangun regency}

Ancol Sarolangun is one of the recreational and inspirational tourism areas located in the city center of Sarolangun. This place is visited by many people every day there are also various kinds of snacks. Besides its strategic place, this area also has an interesting view. And in Ancol every year it becomes a place for celebrations such as 17 August and Eid celebrations.

\subsection{Special Findings}

a. Main Facilities

1) Beatrix

Based on the results of research on the management of tourism object facilities Ancol Sarolangun district in Beatrix starting from planning Show that for the future planning already exists but to implement it maybe next year it will be carried out if there are no obstacles, management Beatrix is not significant but it will be organized properly. Manager has also proposed about cleaning up the garbage is under the Beatrix area but it hasn't been done yet usually the garbage is cleaned when there will be an Eid celebration only. Supervision of the Beatrix is often carried out by the manager and also local residents, to monitor if there are problems in Beatrix.

b. Supporting Facilities

1) Toilet

Based on the results of research on the management of tourism object facilities Ancol Kabupaten Sarolangun in toilet, planning for additions construction of a toilet already exists, there is no organization whatsoever because of the toilet currently only managed by the local community, briefings only focused on cleanliness and comfort while in the toilet, people who manage to keep an eye on the toilet whether the toilet is always clean and well-directed.

2) Trash can

Based on the results of research on the management of tourism object facilities Ancol Sarolangun District in the Trash. Planning for the addition of the trash can already 
exists, but behind can confirm when it will be will lakakanakan, organizing for the trash has not been significant because there is no trash can for visitors, pengarhan is done by direct cleaning officers, supervision is carried out by officer's cleanliness and the merchants respectively

\section{3) Gazebo}

Based on the results of research on the management of tourism object facilities Ancol, Sarolangun Regency regarding Gazebo in Ancol area. From Dinas Tourism is only planning to repair the gazebo paint, organizing for the gazebo carried out by the manager and the surrounding community, the direction is more directed to visitors to always maintain the facility that has been available, this supervision is carried out by managers and the community local area to see the condition of the gazebo to keep it clean and safe.

c. Complementary Facilities

1) Parking area

Based on the results of research on the management of tourism object facilities Ancol Sarolangun regency about parking area. The Tourism Office already exists plan a parking space. The Tourism Office and its managers are organizing for a place that will be used as a parking area, for direction parking space is not carried out properly so that it makes visitors parking irregular vehicles, managers and the surrounding community already trying to supervise the vehicle so as not to put the vehicle down road side

\section{2) Game}

Based on the results of research on the management of object facilities Ancol tourism Sarolangun regency about games for planning there are already plans to add games but it has not been implemented for Currently, there is still nothing organized for the game, Briefing given by the service for game management to be really deep managing the game, for more supervision of visitors' parents in order to keep the children while playing.

\section{Discussion}

The results of this study are a description of the management of the object facilities Ancol Tourism Sarolangun Regency Facility Management is a process organizing planning, direction and supervision of a facility and infrastructure which must be provided by the manager for the needs of visitors According to Supriadi and Roedjinandari (2017,224), Facilities support the creation of convenience, comfort, safety of tourists, inside visits. Is a means specifically intended for It can be seen that the existing facilities have not attracted visitors comfortable? Therefore, it is expected that the management and the Tourism Office to always supervise existing facilities and organize and maintain existing facilities there so that visitors are comfortable and for future planning for the Tourism Office could seriously build additional facilities at the Ancol Regency Tourism Object Sarolangun

\section{Conclusion}

The conclusion is: Planning for the Management of Ancol Tourism Objects in Saolangun Regency in tinjuau from the musty planning that is not well structured. Planning that gives by the tourism office which is still slowly advancing the Tourism Object Ancol, 
Kabupaten Saolangun Planning that has been prepared by the DinasTourism, namely planning to build a toilet, adding games, addition of trash bins and planning for making parking spaces as well fix paint on the gazebo. Organizing The organizing of tourist attraction managers is only shown in management of existing toilets, existing gazebos. As for the parking lot can't organize it yet because the parking 1 or doesn't exist yet. The briefing of the manager of the Ancol tourism object in Sarolangun Regency carried out directions to the cleanliness of the ancol area. Beatrix area maintenance as well perform redirects for missing game additions to the object Ancol Tourism in Sarolangun District. Supervision The manager of Ancol tourism object in Sarolangun Regency is not very good significantly supervise the facilities, especially the place parking is difficult to control and on the supervision of cleanliness and against Beatrix.

Suggestion is: For the Sarolangun Regency Tourism Office and the manager of Ancol tourism objects Sarolangun regency regarding this research can be a deep direction improve management at Ancol Tourism Objects regarding planning, organization, direction, and supervision. For the community around Ancol Tourism Object, research can be practiced for everyday life. Especially for the management of existing facilities. For later researchers who want to do research that will make about promotional strategies or visitor perceptions of visiting tourist objects Ancol for the future. For tourism majors, especially D4 Hospitality Management students can make reference material for further research.

\section{References}

[1] Adisasmita. 2011, Revenue Management, Grahalimu, Yogyakarta

[2] AmirullahHaris. 2016. Management Basics. Jakarta. Earth Literacy

[3] Arikunto. 2010 Research Procedure: A Practice Approach. Jakarta: Rineka Create

[4] Sugiyono 2018 Qualitative Research Methods. Bandung Alphabetas

[5] Supriadi, Bambang and Roedjinandari. Nanny. 2017. Planning and Development of Tourist Destinations. Malang State University of Malang Republic of Indonesia Law NO. 10 of 2009 concerning Tourism 